\title{
Length-weight Relationships, Condition and Population Structure of the Genus Atlantoraja (Elasmobranchii, Rajidae, Arhynchobatinae) in Southeastern Brazilian Waters, SW Atlantic Ocean
}

\author{
María Cristina Oddone \\ Universidade Estadual Paulista, Instituto de Biociências, \\ Departamento de Ecologia, Campus Rio Claro, Av. 24-A 1515, CP: 199, \\ CEP: 13506-900, Rio Claro, SP, Brazil. \\ Email: mcoddone@rc.unesp.br \\ Alberto Ferreira de Amorim \\ Instituto de Pesca, Av. Bartolomeu de Gusmão, 192, Ponta da Praia, \\ CEP: 11030-906, Santos, SP, Brazil.
}

\begin{abstract}
Oddone, M. C., and A. F. Amorim 2007. Length-weight Relationships, Condition and Population Structure of the Genus Atlantoraja (Elasmobranchii, Rajidae, Arhynchobatinae) in Southeastern Brazilian Waters, SW Atlantic Ocean. J. Northw. Atl. Fish. Sci., 38: 43-52. doi:10.2960/J.v38.m599
\end{abstract}

\begin{abstract}
During the present study, 107 specimens of Atlantoraja castelnaui, 188 of A. platana, and 770 of $A$. cyclophora, were obtained by commercial vessels operating in Southeastern Brazil from March 2005 to April 2006. Males of $A$. castelnaui ranged from 17.9-111.0 cm and females from 17.4-116.0 $\mathrm{cm}$ total length. Males of $A$. platana ranged from $13.1-70.0 \mathrm{~cm}$ and females from $12.5-76.0 \mathrm{~cm}$ total length. Males of $A$. cyclophora ranged from $13.3-58.5 \mathrm{~cm}$ and females from $11.5-68.0 \mathrm{~cm}$ total length. Length-weight curves were sexually dimorphic in the three species. The analysis of the angular coefficient $(b)$ demonstrated that growth (in weight) in relation to length was allometric $(b>3)$ in males of $A$. castelnaui and A. platana, while isometric $(b=3)$ in females of these species. Conversely, growth of $A$. cyclophora was isometric in males, while in females it was allometric $(b>3)$. The condition factor varied significantly throughout the year only in females of $A$. castelnaui.

Key words: angular coefficient, condition factor, elasmobranch, morphometrics, skates.
\end{abstract}

\section{Introduction}

The genus Atlantoraja Menni, 1972, comprises three species, the Eyespot skate A. castelnaui (Ribeiro 1907), the La Plata skate A. platana (Günther 1880) and the Spotback skate A. cyclophora (Regan 1903) (Compagno, 2005). All are endemic to the Western Atlantic coast of South America. Atlantoraja castelnaui ranges from Rio de Janeiro State in Brazil to Argentina at depths of 20-220 m (Vooren, 1998), where it is the largest and one of the most common rajids in the Southern Brazilian and Bonaerensean districts (Figueiredo, 1977; Menni, 1973; Menni et al., 1981). Atlantoraja platana ranges from the littoral of São Paulo State in Brazil to Argentina (Figueiredo, 1977), where it is part of the Bonaerensean fauna (Menni and Lopez, 1984). In Southern Brazil, it is found between 40-100 m depth (Vooren, 1998), although Marçal (MS 2003) has recorded the occurrence of this species at depth of up to $231 \mathrm{~m}$. Atlantoraja cyclophora occurs from Cabo Frio in Rio de Janeiro State, Brazil, to Argentina (Figueiredo, 1977) and is found from the coast to depths of up to $300 \mathrm{~m}$ (Oddone and Vooren, 2004). However, the observed upper limit of its depth distribution in Southern Brazil is $40 \mathrm{~m}$ (Vooren, 1998). Furthermore, Gosztonyi (1981) recorded the occurrence of A. cyclophora off the Buenos Aires Province at depths of 26-71 m. In Argentinean waters, A. cyclophora is distributed within the Southern Brazilian and Bonaerensean zoogeographical districts. Menni and Lopez (1984) have placed this species within the inner shelf mixed fauna, where it has been observed at depths of up to $89 \mathrm{~m}$.

In Southern Brazilian waters, the three species are sympatric and occur throughout the year without seasonal variations in abundance, sex, or size (Vooren, 1998; Vooren and Klippel, 2005). In the Uruguayan inner shelf, Atlantoraja castelnaui along with A. cyclophora and Rioraja agassizi are distributed in $30-60 \%$ of the area, 
with abundances between $1000-5000 \mathrm{~kg} / \mathrm{square}$ nautical miles (Paesch, MS 2006).

Atlantoraja castelnaui, A. platana and A. cyclophora all have a high commercial value. In Southern Brazil, A. castelanui has been commercially landed at least since 1986 and was frequently observed in trawler landings in 2002 and 2003, while in Argentina, this species has been landed since 1994 (Hozbor et al., 2004). Detailed landing statistics are not available because all species of batoids are recorded as "unidentified rays and skates". Trawl fishing in the habitat of $A$. castelanui is intense, and off the coast of Uruguay and Argentina, the biomass of $A$. castelnaui decreased by $75 \%$ from 1994-1999 (Hozbor et al., 2004). Atlantoraja spp., particularly the larger individuals, are commonly landed in Santos and Guarujá (Oddone, unpublished data). Since 1999, the meat of the three species has been exported to Asia, in particular to South Korea. In Santos alone, just one fishing company exported 100 tons of skates of the genera Atlantoraja and Rioraja during 2002 (Casarini, MS 2006). Intensive fisheries in the Southwestern Atlantic have led to the overexploitation of several species of demersal elasmobranchs (Vooren and Klippel, 2005), leading $A$. castelnaui and A. cyclophora to become endangered (Hozbor et al., 2004) and a matter of concern for the conservation of these species. Yet no information on the conservation status of $A$. platana is available.

The aims of the present work were to analyze the composition, length-weight relationships and general condition of the species in the genus Atlantoraja present in the area exploited by the fishing fleet of Santos and Guarujá (Southeastern Brazil).

\section{Materials and Methods}

One hundred and seven specimens of $A$. castelnaui, 188 of A. platana, and 770 of A. cyclophora were obtained by seven commercial vessels operating at the Southeastern Brazilian waters. The number of individuals per species, sex and month is presented in Table 1.

Monthly samples were taken from March 2005 to April 2006 by single and pair trawlers ranging in length from $19.5-22.5 \mathrm{~m}$ and beam trawlers from $5.3-13 \mathrm{~m}$. The stretched mesh of the trawl net varied from 45-90 $\mathrm{mm}$ and the ground-rope ranged from $22-70 \mathrm{~m}$. Data collected by fishermen for each trawl were: date, depth, latitude and longitude. Data on number of hauls and number of hauls with occurrence of the species are uncertain. The study area was situated between latitudes $23^{\circ} 37^{\prime} \mathrm{S}$ and $27^{\circ} 40^{\prime} \mathrm{S}$, covering the States of Rio de Janeiro, São Paulo, Paraná and Santa Catarina, at depths varying between 10-146 m (Fig. 1).

Biometric measurements collected were total length (TL, cm), total disc width (DW, cm), total weight $\left(\mathrm{W}_{\mathrm{T}}\right.$, $\mathrm{g}$ ), and gutted weight ( $\mathrm{W}_{\mathrm{G}}$, body weight without digestive tract, liver and reproductive organs, g). Gutted weight is considered to be a more appropriate variable than total weight because the former is not influenced by individual variation of mass in the digestive tract, liver, and reproductive organs (Perez and Vooren, 1991). Linear measurements were carried out with $0.1 \mathrm{~cm}$ precision. Two electric scales were used, with 1 and $5 \mathrm{~g}$ precision.

The Condition Factor based on total weight $\left(\mathrm{CF}_{\mathrm{T}}\right)$ and gutted weight $\left(\mathrm{CF}_{\mathrm{G}}\right)$ was, respectively, calculated according to King (1995) from:

and

$$
C F_{T}=W_{T} / T L^{b}
$$

$$
C F_{G}=W_{G} / T L^{b},
$$

where $b$ is the angular coefficient of the potential curve adjusted to the respective length-weight relationships.

Parametric/non-parametric tests were chosen by testing the normality and homogeneity of variance in the variables using the Lilliefors' and Levene's tests, respectively. To compare length-weight curves, the data were log-transformed to linearize the regression and the $F$-test used (Souza 1998). Sex ratio (M:F) was tested using the chi-squared test $\left(\chi^{2}\right)$. To assess the nature of the growth in weight with TL (isometry/allometry), the value of the angular coefficient $b$ was compared with the theoretical value of 3. Comparisons among median $\mathrm{CF}$, obtained monthly for all individuals, were performed using Kruskal-Wallis' H-test and post-hoc Mann-Whitney's U-test Bonferroni corrected (Sokal and Rohlf, 1995) using the freeware software PAST (Hammer et al., 2001). In all analyses, the significance level considered was 0.05 .

\section{Results}

\section{Total length and sex composition}

The size distribution, and sex ratio by month, for the three species are presented in Fig. 2 and Table 1, respectfully.

Atlantoraja castelnaui was captured at depths of 24-120 m Males ranged from 17.9-111.0 cm TL and 
TABLE 1. Length (cm) and number ( $n$ ) of male and female Atlantoraja castelnaui, A. platana and A. cyclophora captured by month. Range, mean and standard deviation of total lengths, and male:female sex ratio, are given.

\begin{tabular}{|c|c|c|c|c|c|c|c|c|c|}
\hline \multirow[b]{2}{*}{ Month } & \multicolumn{4}{|c|}{ Males } & \multicolumn{4}{|c|}{ Females } & \multirow{2}{*}{$\frac{\text { Sex ratio }}{\mathrm{M}: \mathrm{F}}$} \\
\hline & $n$ & range & mean & SD & $n$ & range & mean & SD & \\
\hline \multicolumn{10}{|c|}{ Atlantoraja castelnaui } \\
\hline Mar 2005 & - & - & - & - & - & - & - & - & - \\
\hline Apr 2005 & 6 & $24.9-80.5$ & 40.1 & 20.5 & 7 & $52.9-116.0$ & 92.2 & 23.2 & $0.9: 1$ \\
\hline May 2005 & 1 & 48.0 & - & - & 5 & $44.0-113.0$ & 80.4 & 32.2 & $0.2: 1$ \\
\hline Jun 2005 & 3 & $34.0-60.0$ & 44.8 & 13.4 & 2 & $28.0-49.8$ & 38.9 & 15.4 & $1: 0.7$ \\
\hline Jul 2005 & 4 & $36.2-86.0$ & 60.2 & 24.0 & 7 & $33.0-94.5$ & 55.9 & 19.7 & $0.6: 1$ \\
\hline Aug 2005 & 5 & $38.8-95.5$ & 72.6 & 23.3 & 1 & - & - & - & $1: 0.2$ \\
\hline Sep 2005 & 7 & $50.0-77.0$ & 65.3 & 11.6 & 8 & $44.3-106.0$ & 66.5 & 19.9 & $0.9: 1$ \\
\hline Oct 2005 & 7 & $48.0-106.0$ & 74.0 & 22.0 & 10 & $48.0-106.0$ & 73.9 & 21.9 & $0.7: 1$ \\
\hline Nov 2005 & 6 & $45.2-111.0$ & 79.0 & 25.4 & 4 & $45.2-111.0$ & 79.0 & 25.4 & $1: 0.7$ \\
\hline Dec 2005 & - & - & - & - & - & - & - & - & - \\
\hline Jan 2006 & 5 & $43.0-95.0$ & 68.4 & 21.6 & 4 & $49.0-61.4$ & 55.4 & 6.6 & $1: 0.8$ \\
\hline Feb 2006 & - & - & - & - & - & - & - & - & - \\
\hline Mar 2006 & 9 & $48.5-101.0$ & 78.0 & 19.3 & 6 & $84.0-104.0$ & 96.0 & 8.1 & $1: 0.7$ \\
\hline Apr 2006 & - & - & - & - & - & - & - & - & - \\
\hline TOTAL & 53 & $17.9-111.0$ & 65.3 & 23.6 & 53 & $17.4-116.0$ & 68.8 & 24.8 & $0.9: 1$ \\
\hline \multicolumn{10}{|c|}{ Atlantoraja platana } \\
\hline Mar 2005 & 3 & $24.3-34.2$ & 29.7 & 5.0 & 4 & $16.8-31.4$ & 24.3 & 6.0 & $0.75: 1$ \\
\hline Apr 2005 & - & - & - & - & 1 & 26.1 & 26.1 & - & - \\
\hline May 2005 & 5 & $36.6-69.0$ & 48.0 & 12.8 & 2 & $25.5-21.1$ & 19.8 & 6.1 & $1: 0.4$ \\
\hline Jun 2005 & 6 & $36.1-63.5$ & 36.1 & 20.5 & 6 & $12.5-75.0$ & 56.0 & 9.9 & $1: 1$ \\
\hline Jul 2005 & 6 & $44.6-48.6$ & 42.2 & 10.6 & 13 & $12.5-75.0$ & 45.8 & 16.7 & $0.5: 1$ \\
\hline Aug 2005 & 5 & $44.6-48.6$ & 46.9 & 1.8 & 13 & $20.8-74.5$ & 45.1 & 18.8 & $0.4: 1$ \\
\hline Sep 2005 & 5 & $31.5-67.0$ & 48.9 & 14.1 & 5 & $28.8-73.0$ & 51.8 & 19.4 & $1: 1$ \\
\hline Oct 2005 & 7 & $48.0-106.0$ & 74.0 & 22.0 & 14 & $19.7-76.0$ & 42.5 & 15.7 & $0.5: 1$ \\
\hline Nov 2005 & 6 & $40.0-55.8$ & 44.8 & 5.9 & 9 & $21.8-75.5$ & 40.0 & 14.7 & $0.7: 1$ \\
\hline Dec 2005 & 13 & $15.5-70.0$ & 42.6 & 17.1 & 4 & $39.4-75.0$ & 52.3 & 16.5 & $1: 0.3^{*}$ \\
\hline Jan 2006 & 16 & $29.5-68.0$ & 40.5 & 8.6 & 4 & $45-75.5$ & 55.9 & 13.4 & $4: 1$ \\
\hline Feb 2006 & 15 & $13.1-62.0$ & 30.3 & 11.9 & 5 & $22.0-72.0$ & 39.2 & 19.3 & $3: 1^{*}$ \\
\hline Mar 2006 & 7 & $15.8-49.5$ & 30.3 & 11.9 & 6 & $24.6-51.0$ & 36.6 & 12.7 & $1: 0.9$ \\
\hline Apr 2006 & 6 & $45.7-59.4$ & 50.4 & 5.4 & 2 & $43.2-49.0$ & 46.1 & 4.1 & $3: 1$ \\
\hline TOTAL & 100 & $13.1-70.0$ & 42.8 & 12.6 & 88 & $12.5-76.0$ & 43.6 & 16.2 & $1: 0.9$ \\
\hline \multicolumn{10}{|c|}{ Atlantoraja cyclophora } \\
\hline Mar 2005 & 5 & $36.9-51.4$ & 43.6 & 5.5 & 5 & $11.6-59.8$ & 44.4 & 19.9 & $1: 1$ \\
\hline Apr 2005 & 3 & $28.8-54.3$ & 38.2 & 14.0 & 16 & $12.0-57.5$ & 39.3 & 12.4 & $0.2: 1^{*}$ \\
\hline May 2005 & 1 & - & 24.4 & & 14 & $25.6-60.0$ & 44.8 & 12.1 & $1: 3.6$ \\
\hline Jun 2005 & 16 & $17.0-57.2$ & 37.2 & 12.7 & 5 & $15.0-58.5$ & 27.5 & 19.9 & $1: 4.4^{*}$ \\
\hline Jul 2005 & 16 & $29.1-58.3$ & 47.8 & 9.2 & 18 & $27.0-60.4$ & 49.4 & 10.9 & $1: 1.9^{*}$ \\
\hline Aug 2005 & 63 & $22.9-58.5$ & 43.9 & 9.7 & 48 & $18.8-62.7$ & 42.5 & 12.8 & $1: 2.3^{*}$ \\
\hline Sep 2005 & 27 & $28.9-54.5$ & 47.3 & 7.4 & 36 & $30.2-61.5$ & 47.3 & 7.7 & $1: 2.4$ \\
\hline Oct 2005 & 46 & $26.0-56.0$ & 40.2 & 7.9 & 38 & $19.5-61.0$ & 38.4 & 9.5 & $1: 1.9$ \\
\hline Nov 2005 & 34 & $27.0-55.0$ & 42.7 & 7.2 & 23 & $25.5-61.0$ & 42.0 & 9.7 & $1: 2.2$ \\
\hline Dec 2005 & 25 & $30.5-56.0$ & 43.1 & 6.7 & 27 & $12.1-59.9$ & 42.8 & 10.4 & $1: 2.3$ \\
\hline Jan 2006 & 42 & $13.4-54.5$ & 39.0 & 9.6 & 59 & $22.0-68.0$ & 37.3 & 9.8 & $1: 2.4^{*}$ \\
\hline Feb 2006 & 18 & $23.5-55.4$ & 39.2 & 9.6 & 23 & $25.0-57.5$ & 40.9 & 9.6 & $1: 2.5$ \\
\hline Mar 2006 & 28 & $30.5-55.0$ & 51.5 & 8.3 & 33 & $24.5-60.3$ & 36.5 & 7.3 & $1: 2.6$ \\
\hline Apr 2006 & 47 & $17.2-56.0$ & 43.3 & 11.2 & 54 & $14.2-62.0$ & 50.1 & 11.1 & $1: 2.7^{*}$ \\
\hline TOTAL & 371 & $13.3-58.5$ & 42.2 & 9.7 & 399 & $11.5-68.0$ & 42.3 & 11.9 & $0.9: 1^{*}$ \\
\hline
\end{tabular}

* significant difference from 1:1 sex ratio at $5 \%$ level. 


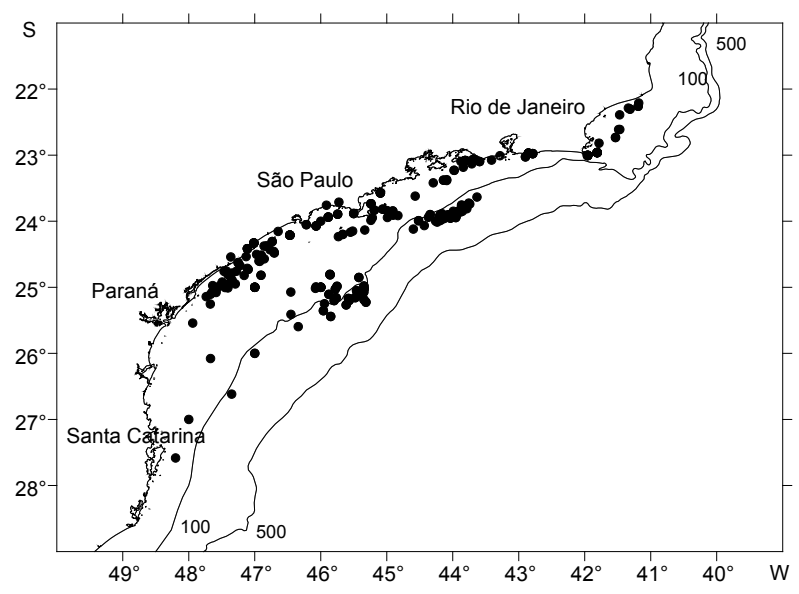

Fig. 1. Map of the study area, Southeastern Brazil, Southwestern Atlantic Ocean. Symbols represent the total number of fishing hauls (when registered by fishermen) in the area where samples of Atlantoraja castelnaui, A. platana and A. cyclophora were collected.

females from 17.4-116.0 cm TL, with no significant difference in the mean total length between sexes. Sex ratio for the total sample resulted in 0.9:1 favoring the females, though not statistically different from 1:1.

Atlantoraja platana was captured at depths between $20-120 \mathrm{~m}$. Males ranged from $13.1-70.0 \mathrm{~cm}$ TL and females from 12.5-76.0 cm TL. Males and females did not differ significantly in their mean total length. Sex ratio for the total sample resulted in 1:0.9, favoring the males, but this difference was not statistically different from 1:1.

Atlantoraja cyclophora was captured between $10-130 \mathrm{~m}$ deep. Males ranged from $13.3-58.5 \mathrm{~cm}$ TL and females from 11.5-68.0 cm TL, with no significant difference in the mean total length between sexes. Sex ratio of this species for the entire sampling was significantly different from 1:1 in favor of the females.

\section{Length-weight and length-width relationships}

For a given length, females of all three species studied were significantly heavier than males (Table 2, Fig. 3 ). In addition, and with the exception of male A. platana, there were significant differences for all comparisons of total length - total weight and and total - gutted weights relationships (Fig. 3).

For A. castelnaui, curves for the relationship TL-DW were significantly different between sexes, and females were slightly wider than males, with the exception of neonates and juveniles (Table 2, Fig. 4A). In A. platana,
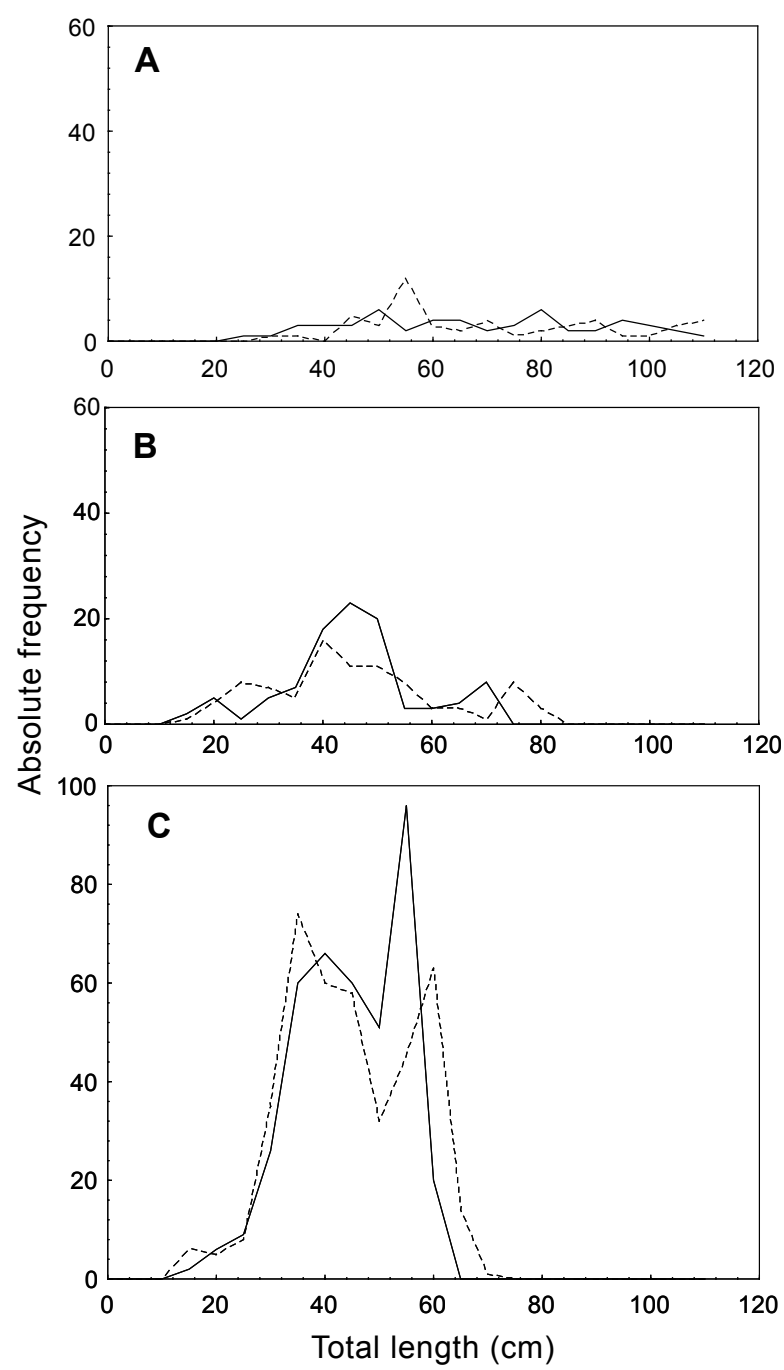

Fig. 2. Absolute frequency of total length $(\mathrm{cm})$ for males (solid lines) and females (dashed lines) for grouped samples of (A) Atlantoraja castelnaui; (B) Atlantoraja platana and (C) Atlantoraja cyclophora.

there was no significant difference in the TL-DW curves between males and females (Table 2, Fig. 4B). Similarly to the patterns observed in A. castelnaui, TL-DW curves were sexually dimorphic in A. cyclophora, with females being wider than males for lengths $>31.4 \mathrm{~cm}$ TL and males wider than females for lengths $<31.4 \mathrm{~cm} \mathrm{TL}$ (Table 2, Fig. 4C).

According to the comparison of the angular coefficient $b$ with the theoretical value of 3 , males of $A$. castelnaui were found to increase in weight in relation to length with positive allometry $(b>3)$ when $\mathrm{W}_{\mathrm{T}}$ was considered. However, when considering $\mathrm{W}_{\mathrm{G}}$, growth became isometric $(b=3)$, and the same result was observed for 
TABLE 2. Relationships analyzed for Atlantoraja spp.: TL $=$ total length (cm); DW = disc width $(\mathrm{cm}) ; \mathrm{W}_{\mathrm{T}}=$ total weight $(\mathrm{g}) ; \mathrm{W}_{\mathrm{G}}=$ gutted weight $(\mathrm{g})$ for males $(\mathrm{M})$ and females $(\mathrm{F})$ along with the respective potential regression equation and correlation coefficient $\left(R^{2}\right)$, sample number $(n)$.

\begin{tabular}{|c|c|c|c|c|c|}
\hline Curve & Sex & Equation & $R^{2}$ & $n$ & Comparison \\
\hline \multicolumn{6}{|c|}{ A. castelnaui } \\
\hline \multirow[t]{2}{*}{ TL-DW } & M & $D W=-0.933+0.706 T L$ & 0.991 & 51 & $F=27.8$, d.f. $=2,96, p=0.00$ \\
\hline & $\mathrm{F}$ & $D W=-0.883+0.716 T L$ & 0.992 & 49 & \\
\hline \multirow[t]{2}{*}{$\mathrm{TL}-\mathrm{W}_{\mathrm{T}}$} & M & $W_{T}=0.0089 T L^{3.193}$ & 0.999 & 50 & $F=1714.8$, d.f. $=2,94, p=0.00$ \\
\hline & $\mathrm{F}$ & $W_{T}=0.0150 T L^{3.117}$ & 0.987 & 50 & \\
\hline \multirow{2}{*}{$\mathrm{TL}-\mathrm{W}_{\mathrm{G}}$} & M & $W_{G}=0.0910 T L^{3.114}$ & 0.919 & 49 & $F=1.8$, d.f. $=2,92, p=0.18$ \\
\hline & $\mathrm{F}$ & $W_{G}=0.0170 T L^{3.087}$ & 0.986 & 49 & \\
\hline \multicolumn{6}{|c|}{ A. platana } \\
\hline \multirow[t]{2}{*}{ TL-DW } & M & $D W=2.623+0.778 T L$ & 0.975 & 100 & $F=2.2$, d.f. $=2,185, p=0.11$ \\
\hline & $\mathrm{F}$ & $D W=4.378+0.730 T L$ & 0.976 & 89 & \\
\hline \multirow[t]{2}{*}{$\mathrm{TL}-\mathrm{W}_{\mathrm{T}}$} & M & $W_{T}=0.0023 T L^{3.307}$ & 0.981 & 94 & $F=49.0$, d.f. $=2,168, p=0.00$ \\
\hline & $\mathrm{F}$ & $W_{T}=0.0023 T L^{3.016}$ & 0.983 & 86 & \\
\hline \multirow[t]{2}{*}{$\mathrm{TL}-\mathrm{W}_{\mathrm{G}}$} & M & $W_{G}=0.0070 T L^{3.289}$ & 0.965 & 96 & $F=10.0$, d.f. $=2,177, p=0.00$ \\
\hline & $\mathrm{F}$ & $W_{G}=0.0140 T L^{2.879}$ & 0.927 & 86 & \\
\hline \multicolumn{6}{|c|}{ A. cyclophora } \\
\hline \multirow[t]{2}{*}{ TL-DW } & M & $D W=2.881+0.678 T L$ & 0.988 & 397 & $F=73.0,2$, d.f. $=2,786, p=0.00$ \\
\hline & $\mathrm{F}$ & $D W=0.952+0.742 T L$ & 0.992 & 405 & \\
\hline \multirow[t]{2}{*}{$\mathrm{TL}-\mathrm{W}_{\mathrm{T}}$} & M & $W_{T}=0.0044 T L^{3.056}$ & 0.987 & 397 & $F=77.0,2$, d.f. $=2,786, p=0.00$ \\
\hline & $\mathrm{F}$ & $W_{T}=0.0027 T L^{3.197}$ & 0.988 & 393 & \\
\hline \multirow[t]{2}{*}{$\mathrm{TL}-\mathrm{W}_{\mathrm{G}}$} & M & $W_{G}=0.0044 T L^{3.039}$ & 0.973 & 385 & $F=19.5,2$, d.f. $=2,786, p=0.00$ \\
\hline & $\mathrm{F}$ & $W_{G}=0.0031 T L^{3.139}$ & 0.988 & 384 & \\
\hline
\end{tabular}

females. In A. platana, males grew with positive allometry while females grew isometrically considering both $\mathrm{W}_{\mathrm{T}}$ and $\mathrm{W}_{\mathrm{G}}$. In A. cyclophora, male growth was found to be isometric, while in females, growth was positively allometric (Table 3).

\section{Condition factor}

For males of A. castelnaui, $\mathrm{CF}_{\mathrm{T}}$ and $\mathrm{CF}_{\mathrm{G}}$ did not vary significantly thorough the year. Conversely, females showed significant variations in both the $\mathrm{CF}_{\mathrm{T}}$ and $\mathrm{CF}_{\mathrm{G}}$ throughout the year $\left(H_{(11, N=51)}=0, p<0.01\right.$; and $H_{(11, N=49)}=0, p<0.01$, respectively). Significant differences in the $\mathrm{CF}_{\mathrm{T}}$ and the $\mathrm{CF}_{\mathrm{G}}$ were detected in September by the post-hoc pair-wise comparisons, when the condition factor reached its lowest value for the females (Fig. 5A).

For A. platana, $\mathrm{CF}_{\mathrm{T}}$ and $\mathrm{CF}_{\mathrm{G}}$ did not vary significantly throughout the year for males or for females (Fig. 5B).
For of A. cyclophora, the $\mathrm{CF}_{\mathrm{T}}$ did not vary significantly for the female $\mathrm{W}_{\mathrm{T}}$. For males, $\mathrm{CF}_{\mathrm{T}}$ did not vary significantly among month. However, the Kruskal-Wallis test detected a slightly significant difference in the $\mathrm{CF}_{\mathrm{G}}$ throughout the year $\left(H_{(13, N=398)}=24.46, p=0.02\right.$, respectively), but it was assumed that no differences were observed among months. This is because the post-hoc Bonferroni corrected tests did not show any significant differences (Fig. 5C).

\section{Discussion}

According to the depth of occurrence, A. cyclophora was more proximal to the coast, whereas $A$. castelnaui and A. platana occurred at depths greater than $24 \mathrm{~m}$ in this area. For A. castelnaui, this fact is reinforced by the observation of Vooren (pers. com., Fundação Universidade Federal do Rio Grande, Brazil) of a $20.2 \mathrm{~cm}$ TL male caught at a depth of $29 \mathrm{~m}\left(33^{\circ} 51^{\prime} 24^{\prime \prime} \mathrm{S}, 52^{\circ} 54^{\prime}\right.$ $36^{\prime \prime} \mathrm{W}$ ) off the coast of Chui, in Rio Grande do Sul State 

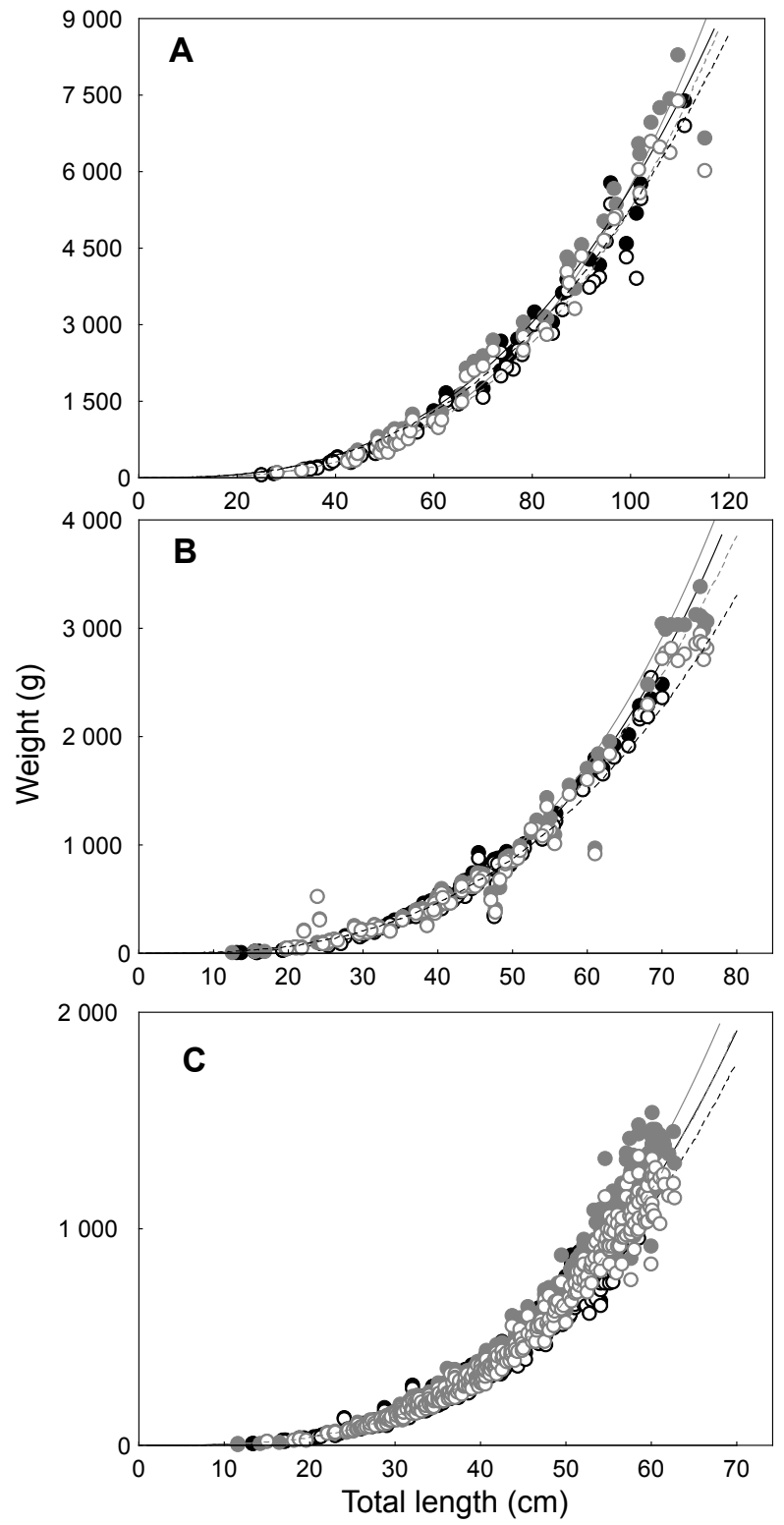

Fig. 3. Comparison of length and total (males = black full circles; females = grey full circles), and length and gutted (g) (males = black empty circles; females grey empty circles) weight relationships, for (A) Atlantoraja castelnaui; (B) Atlantoraja platana and (C) Atlantoraja cyclophora. Black lines, represent the adjusted potential curve for males regarding to total weight (solid lines) and gutted weight (dashed lines). Grey lines represent the adjusted potential curve for the females regarding total weight (solid lines) and gutted weight (dashed lines).

(Brazil). Ponz Louro (MS 1995) reported the presence of A. castelnaui in the range of 35-100 m, but the upper limit of the surveys was only $100 \mathrm{~m}$. According to the author, this species is rarely found in groups, being
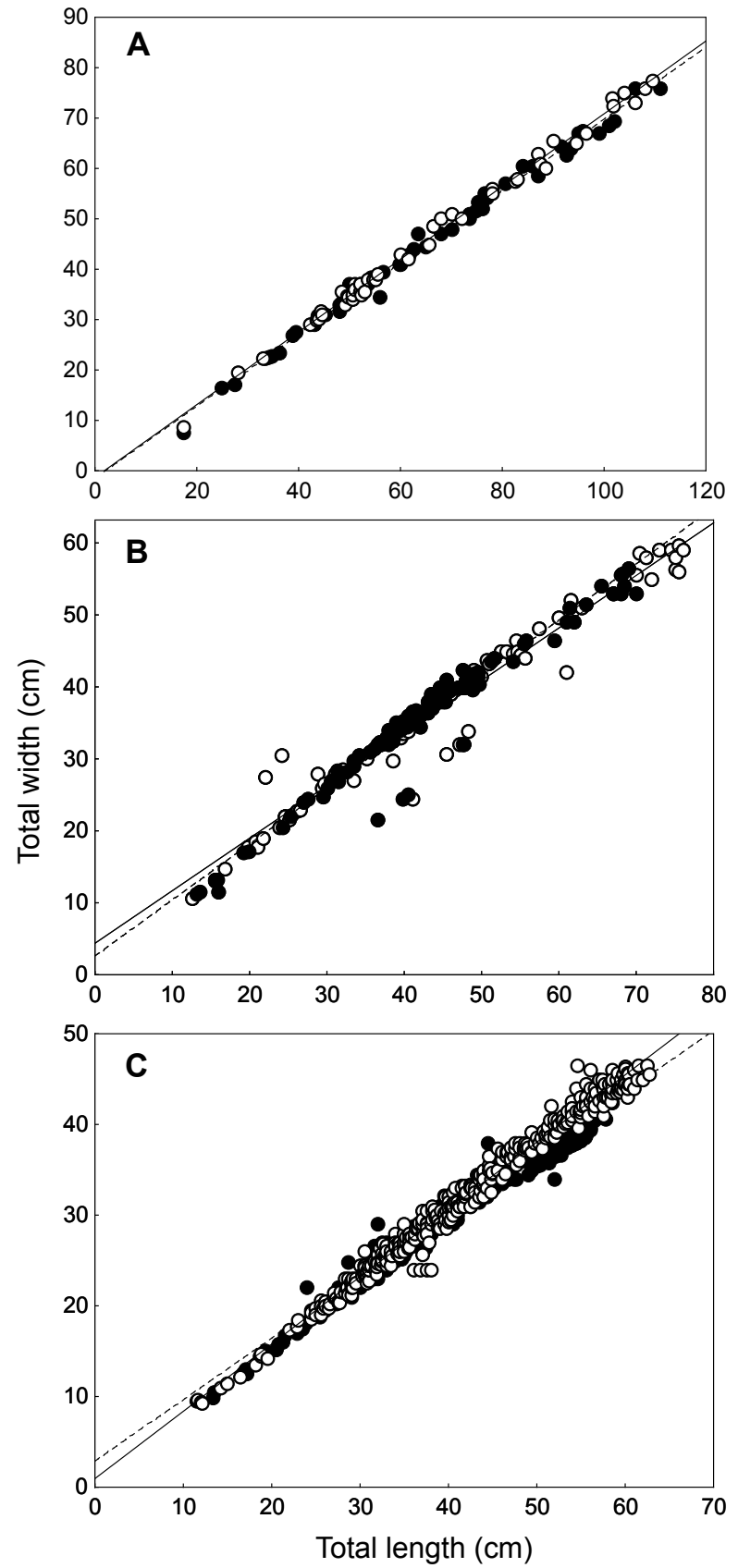

Fig. 4. Relationship between disc width (cm) as dependent variable of total length $(\mathrm{cm})$ for males (black solid symbols, solid lines) and females (black empty symbols, dashed lines) for (A) Atlantoraja castelnaui; (B) Atlantoraja platana and (C) Atlantoraja cyclophora.

found solitary or at most in pairs (in Southeastern Brazil) with juveniles presumably distributing in areas of up to $50 \mathrm{~m}$ deep and adults between 50 and $100 \mathrm{~m}$. According to Vooren (1998), A. platana is known to occur at depths of up to $110 \mathrm{~m}$ in Southern Brazil, though Marçal (MS 2003) recorded the presence of this species at depths of 
TABLE 3. Estimate of the angular coefficient ( $b$ ) for males and females of Atlantoraja spp.; standard error (SE) of the regression total length-total/gutted weight, $\mathrm{t}_{1}=t$-test value of the regression and $\mathrm{p}_{1}=$ probability of the regression regarding $b$, correlation coefficient of the regression $r$, d.f. = degrees of freedom and probability $\left(\mathrm{p}_{1}\right), \mathrm{t}_{2}=t$-test's value of the comparison with the theoretical value 3 and probability $\left(\mathrm{p}_{2}\right)$ and the nature of growth according to $b$.

\begin{tabular}{|c|c|c|c|c|c|c|c|c|c|c|}
\hline Sex & Ratio & $b$ & $\mathrm{SE}$ & $\mathrm{t}_{1}$ & $\mathrm{p}_{1}$ & $r$ & d. f. & $\mathrm{t}_{2}$ & $\mathrm{p}_{2}$ & growth \\
\hline \multicolumn{11}{|c|}{ A. castelnaui } \\
\hline \multirow[t]{2}{*}{ Males } & $\mathrm{W}_{\mathrm{T}}$ & 3.193 & 0.048 & 67.1 & 0.00 & 0.99 & 49 & 4.15 & $<0.05$ & allometric + \\
\hline & $\mathrm{W}_{\mathrm{G}}^{\mathrm{T}}$ & 3.114 & 0.077 & 40.6 & 0.00 & 0.99 & 49 & 1.49 & $>0.05$ & isometric \\
\hline \multirow[t]{2}{*}{ Females } & $\mathrm{W}_{\mathrm{T}}$ & 3.117 & 0.058 & 53.9 & 0.00 & 0.99 & 50 & 2.02 & $<0.05$ & allometric + \\
\hline & $\mathrm{W}_{\mathrm{G}}$ & 3.087 & 0.058 & 53.2 & 0.00 & 0.99 & 50 & 1.50 & $>0.05$ & isometric \\
\hline \multicolumn{11}{|c|}{ A. platana } \\
\hline \multirow[t]{2}{*}{ Males } & $\mathrm{W}_{\mathrm{T}}$ & 3.307 & 0.045 & 73.0 & 0.00 & 0.99 & 94 & 6.78 & $>0.05$ & allometric + \\
\hline & $\mathrm{W}_{\mathrm{G}}$ & 3.289 & 0.047 & 69.3 & 0.00 & 0.99 & 96 & 6.10 & $>0.05$ & allometric + \\
\hline \multirow[t]{2}{*}{ Females } & $\mathrm{W}_{\mathrm{T}}$ & 3.016 & 0.062 & 48.4 & 0.00 & 0.98 & 87 & 0.26 & $<0.05$ & isometric \\
\hline & $\mathrm{W}_{\mathrm{G}}$ & 2.879 & 0.131 & 36.0 & 0.00 & 0.97 & 85 & 0.92 & $<0.05$ & isometric \\
\hline \multicolumn{11}{|c|}{ A. cyclophora } \\
\hline \multirow[t]{2}{*}{ Males } & $\mathrm{W}_{\mathrm{T}}$ & 3.056 & 0.032 & 94.0 & 0.00 & 0.99 & 392 & 1.75 & $<0.05$ & isometric \\
\hline & $\mathrm{W}_{\mathrm{G}}$ & 3.039 & 0.032 & 96.0 & 0.00 & 0.99 & 384 & 1.24 & $<0.05$ & isometric \\
\hline \multirow[t]{2}{*}{ Females } & $\mathrm{W}_{\mathrm{T}}$ & 3.197 & 0.037 & 86.6 & 0.00 & 0.99 & 393 & 5.39 & $>0.05$ & allometric + \\
\hline & $\mathrm{W}_{\mathrm{G}}$ & 3.139 & 0.034 & 89.1 & 0.00 & 0.99 & 384 & 4.07 & $>0.05$ & allometric + \\
\hline
\end{tabular}

up to $231 \mathrm{~m}$. Atlantoraja cyclophora is found as deep as $300 \mathrm{~m}$ in Southern Brazil (Oddone and Vooren, 2004) and no shallower than $35 \mathrm{~m}$ off the Southeast coast of Brazil (Ponz Louro, MS 1995).

Based on the landing data, the three Atlantoraja species occurred sympatrically throughout the year in Southeastern Brazil. Moreover, the presence of eggbearing females and young individuals suggests that these species (Oddone, pers. obs.) complete their life cycles in the same area, as observed by Vooren (1998) in Southern Brazilian waters.

In spite of the sex ratio being different from the expected 1:1 for the three species, this difference (though statistically significant in some cases) may have no biological significance because of the small sample size. Therefore, it can be assumed that males and females share the same area throughout the year and total segregation between sexes does not occur. This has been previously documented for A. castelnaui and R. agassizi (Ponz Louro, MS 1995; Oddone et al., 2007) in this area and for $A$. cyclophora (Oddone, MS 2003; Oddone and Vooren, 2004) and A. platana (Marçal, MS 2003) in Southern Brazilian waters.

Although the complete range of lengths was represented in the current study, no definitive conclusions on the population structure can be made at this time. When an analysis is dependent on the commercial fishing fleet, information is patchily distributed in time and space, and our perception of the ecology of skates is based just on 'fleeting images' (Walker, MS 1999). Moreover, due to the commercial importance of these species, larger specimens are retained for commercial use. Therefore, only juveniles of each species are provided to researchers by the commercial fishing industry. Thus, the samples obtained in the present study, are biased by fishermen selection. Further research surveys are, therefore, needed to determine the stock size of these species, in South and Southeastern Brazil.

In most rajids, sexual dimorphism is commonly reflected in the mean size (Jardas, 1973; Nottage and Perkins, 1983; Oddone and Vooren, 2004; Oddone et. al., 2007) and the length-weight and length-width curves (Braccini and Chiaramonte, 2002; Mabragaña et al., 2002; Oddone and Vooren, 2004; Oddone et al., 2007). A growth pattern in which males have a wider disc width than females in the first life stages, and in later stages females become wider, was also observed for $R$. agassizi and for samples of $A$. cyclophora from Southern Brazil (Oddone, MS 2003; Oddone and Vooren, 2004; Oddone et al., 2007).

Allometric growth with $b>3$ means that fish become more rotund when length increases, and at the same time, condition factor increases with increasing length (Jones 

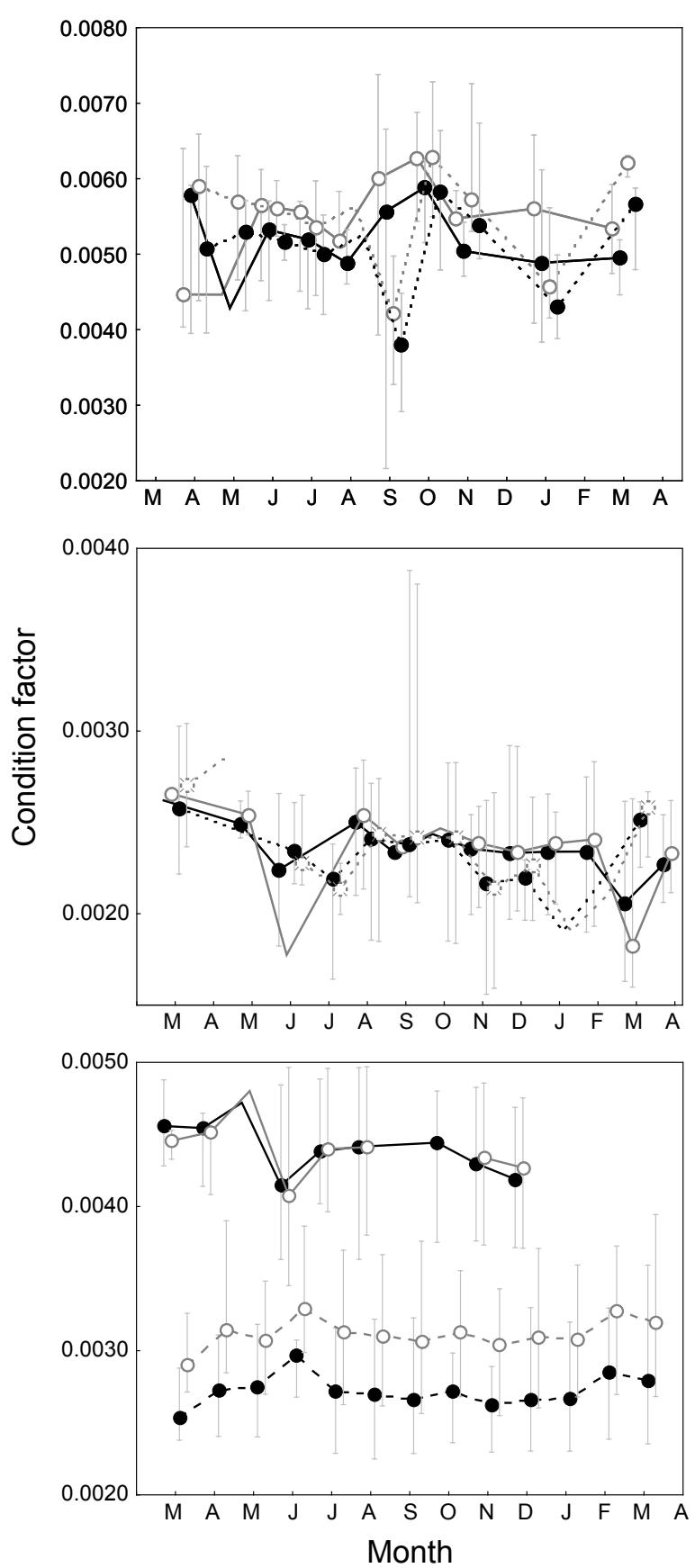

Fig. 5. Median condition factor by month (from March 2005 to April 2006) considering total ( $\mathrm{W}_{\mathrm{T}}$, g, black lines, dotted black circles) and gutted weight $\left(\mathrm{W}_{\mathrm{G}}\right.$, $\mathrm{g}$, grey lines, empty grey circles) for males (solid lines) and females (dashed lines) of (A) Atlantoraja castelnaui; (B) Atlantoraja platana and (C) Atlantoraja cyclophora. Vertical bars represent the data interval.

et al., 1999). In the present work, the data available indicated that males and females of $A$. castelnaui grow with positive allometry with length when considering total weight, however, when gutted weight was considered, growth became isometric. On the other hand, males of $A$. platana were found to grow allometrically with length $(b>3)$ while females grew isometrically. In A. cyclopho$r a$, growth was isometric for males and allometric $(b>3)$ for females.

In addition, it was observed that condition factor significantly varied among months for females of $A$. castel$n a u i$, and in males and females of $A$. cyclophora, which showed significant variation in males only when considering $\mathrm{CF}_{\mathrm{T}}$. These facts could be reflecting variations in food abundance or reproductive stage of the stock (King, 1995). Apparently, the reproductive cycle for this species is annual and therefore, there are neither specific periods for vitellogenesis nor delimited spawning season (Oddone and Vooren, 2005; Oddone, unpublished data), which would reflected in the overall condition of the skates. This detected variation may be better related with food availability or other extrinsic factors ruling the population level. Possible effects of stomach contents on the weight of the skates were avoided by considering gutted weight in the calculations of $b$ and condition factor. This hypothesis is reinforced by the samples of $A$. cyclophora in Southern Brazil, where values of $b<3$ were obtained. Templeman (1987) noted that in Amblyraja radiata, there was not only a dimorphic length-weight relationship but also variations among maturity stages. Mature specimens have lower average weights than immature individuals of the larger size-groups. Overall condition could also be related to alterations in population density (Braga, 1986). Seasonal variation of the diet seems to be associated with the availability of prey, whose distribution and abundance are related to the dynamics of the water masses in the region (Muto et al., 2001). Braccini and Chiaramonte (2002) recorded isometric growth for males and positive allometry in females of Psammobatis extenta. In $R$. agassizi, growth was allometric, with $b<3$ for both sexes (Oddone et al., 2007). The study of fish condition assumes that heavier fish of a given length are in better state, and this has been used by fish culturists as indicators of the general 'well-being or fitness' of the population under consideration (Jones et al., 1999).

The background of biological data of Southwestern Atlantic rajids is still limited. For most species, life history trends are still unknown and this is a matter of concern because fisheries have negatively affected the rajids, which in part is because of their sedentary nature. As a result, the local extinction of several species has occurred, leaving another portion of the population in a critical situation (Brander, 1981; Dulvy and Reynolds, 2002). 
As early as 1933, Steven (1933) was already aware that skates would be rapidly and more severely affected than any other fish by intense fishing in a particular area, in the view that migrations would be restricted or nonexistent. Dulvy and Reynolds (2002) demonstrated that the skate species that have disappeared from substantial parts of their ranges ("locally extinct") have large body sizes compared with all other skates, but that latitudinal and depth ranges were similar to those of other species. According to these authors, the body size correlations may be due to higher mortality rates and correlations with life-history parameters, such as late age at maturity. This is a matter of concern especially for A. castelnaui, which attains more than $110 \mathrm{~cm} \mathrm{TL}$, is the largest rajid inhabiting that depth range in the area, and fits in the Dulvy and Reynolds' category of vulnerable skates to overexploitation and subsequent population depletion.

\section{Acknowledgements}

Special thanks to Gonzalo Velasco, Walter Norbis, Paul G. Kinas, Patricia Mancini, skippers of the C/V Cigano do Mar II and III; Antares I and Polares III; Franzese III; São Paulo IV; São Paulo II; Dourado and Araguaia; São Paulo VI and XI, Jangadeiro XV and to two anonymous referees who critically improved the submitted version of the manuscript with valuable comments and suggestions. This study was funded by FAPESP (Fundação de Amparo à Pesquisa do Estado de São Paulo, Brazil).

\section{References}

BRACCINI, J. M., and G. E. CHIARAMONTE. 2002. Reproductive Biology of Psammobatis extenta. J. Fish Biol., 61: 272-288. doi:10.1111/j.1095-8649.2002.tb01752.x

BRAGA, F. M. S. 1986. Estudo entre fator de condição e relação peso/comprimento para alguns peixes marinhos. $R e$ vista Brasileira de Biologia, 46(2): 339-346.

BRANDER, K. 1981. Disappearance of common skate Raia batis from Irish Sea. Nature, 290: 48-49. doi:10.1038/ $290048 \mathrm{a} 0$

CASARINI, L. M. MS 2006. Dinâmica populacional de raias demersais do gênero Atlantoraja e Rioraja (Elasmobranchii, Rajidae) da costa sudeste e sul do Brasil. PhD Thesis, Universidade de São Paulo, São Paulo, Brazil.

COMPAGNO, L. J. V. 2005. Checklist of living Chondrichthyes. In: Reproductive biology and phylogeny of chondrichthyes, Sharks, batoids and chimaeras. W. C. Hamlett (ed.). Science Publishers, Inc. Enfield (NH), USA. P. 503-548.

DULVY, N. K., and J. D. REYNOLDS. 2002. Predicting extinction vulnerability in skates. Conserv. Biol., 16, 440450. doi:10.1046/j.1523-1739.2002.00416.x

FIGUEIREDO, J. L. 1977. Manual de Peixes Marinhos do Sudeste do Brasil. Introdução: caçoes, raias e quimeras. Museu de Zool. Univ. De São Paulo, 104 p.

GOSZTONYI, A. E. 1981. Resultados de las investigaciones ictiológicas de la campaña I del B/I "Shinkai Maru" en el Mar Argentino (10.04-09.05.1978). En Campañas de investigación pesquera realizadas en el Mar Argentino por los B/I "Shinkai Maru" y "Walther Herwig" y el B/ P "Marburg", años 1978 y 1978. Resultados de la parte Argentina. Angelescu V. ed. Contr. INIDEP, No. 383: 254-266.

HAMMER, O., D. A. T. HARPER, and P. D. RYAN. 2001. PAST: Palaeontological Statistics software package for education and data analysis. Palaeontologica Electronica, 4: 1-9. (Version 1.46, July 2006)

HOZBOR, N., A. MASSA, and C. M. VOOREN. 2004. Atlantoraja castelnaui. In: 2006 IUCN Red List of Threatened Species. IUCN 2006. (www.iucnredlist.org, Downloaded on 12 February 2007.)

JARDAS, I. 1973. A contribution to our knowledge of the biology and ecology of thornback ray (Raja clavata L.) and brown ray (Raja miraletus L.) in the Adriatic. Acta Adriat., 15: 1-42.

JONES, R. E., R. J. PETRELL, and D. PAULY. 1999. Using modified length-weight relationships to assess the condition of fish. Aquacult. Eng., 20: 261-276. doi:10.1016/ S0144-8609(99)00020-5

KING, M. 1995. Fisheries biology, assessment and management. Fishing News Books, UK, 341 p.

MABRAGAÑA, E., L. O. LUCIFORA, and A. M. MASSA. 2002. The reproductive biology and abundance of Sympterygia bonapartii endemic to the south-west Atlantic. $J$. Fish Biol., 60: 951-967.

MARÇAL, A. S. MS 2003. Biologia reprodutiva de Atlantoraja platana (GÜNTHER 1880) (Elasmobranchii: Rajidae) no Sul do Brasil. MSc Thesis, Universidade Federal de Rio Grande, Rio Grande do Sul, Brazil.

MENNI, R. C. 1973. Rajidae del litoral bonaerense. I. Espécies de los géneros Raja, Bathyraja y Sympterygia (Chondrichtyes). Physis, A, 32: 413-439.

MENNI, R. C., and H. L. LÓPEZ. 1984. Distributional Patterns of Argentine Marine Fishes. Physis, A, 42: 71-85.

MENNI, R. C., H. L. LÓPEZ, and M. L. GARCÍA. 1981. Lista comentada de las especies de peces colectadas durante la campaña V del B/I "Shinkai Maru" en el Mar Argentino. Contribuciones del Instituto Nacional de Investigaciones Pesqueras No. 383: 267-280.

MUTO, E. Y., L. S. H. SOARES, and R. GOITEN. 2001. Food resource utilization of the skates Rioraja agassizi (Müller and Henle, 1841) and Psammobatis extenta (Garman, 1913) on the continental shelf off Ubatuba, South-eastern Brazil. Rev. Bras. Biol., 61: 217-238. doi:10.1590/S003471082001000200005

NOTTAGE, A. S., and E. J. PERKINS. 1983. Growth and maturation of rooker Raja clavata L. in the Solway Firth. J. Fish Biol., 23, 43-48. doi:10.1111/j.1095-8649.1983. tb02880.x

ODDONE, M. C. MS 2003. Biologia reprodutiva de Atlantoraja cyclophora (REGAN, 1903) no Sul do Brasil. Rio Grande. MSc Thesis, Fundação Universidade Federal do Rio Grande, Rio Grande do Sul, Brazil.

ODDONE, M. C., A. AMORIM, P. L. MANCINI, and W. NORBIS. 2007. Size composition, monthly condition factor and morphometrics for fishery-dependent samples 
of Rioraja agassizi (Chondrichthyes, Rajidae), endemic to the SW Atlantic Ocean. Neotropical Ichthyology, 5(3): 415-424.

ODDONE, M. C., and C. M. VOOREN. 2004. Distribution and abundance of Atlantoraja cyclophora (Regan 1903) (Elasmobranchii, Rajidae) with regard to salinity, temperature and depth in southern Brazil, south-western Atlantic. Neotrop. Ichthyol., 2: 137-144.

2005. Reproductive biology of Atlantoraja cyclophora (Regan 1903) (Elasmobranchii, Rajidae) off southern Brazil. ICES J. Mar. Sci., 62: 1095-1103. doi:10.1016/ j.icesjms.2005.05.002

PAESCH, L. MS 2006. Estructura de la comunidad de elasmobranquios demersales en el Río de la Plata y su frente oceánico. MSc Thesis, Facultad de Ciencias, Universidad de la República, Montevideo, Uruguay.

PEREZ, B. M., and C. M. VOOREN. 1991. Sexual development, reproductive cycle, and fecundity of the school shark Galeorhinus galeus off southern Brazil. Fish. Bull., 89: $655-667$.

PONZ LOURO, M. MS 1995. Estratégias e tácticas reprodutivas de elasmobrânquios no ecossistema e Ubatuba, SP, Brasil. MSc Thesis, Universidade de São Paulo, São Paulo, Brazil.
SOUZA, G. S. 1998. Introdução aos Modelos de Regressão Linear e Não-Linear. Brasília: EmbrapaSPI / Embrapa -SEA. 505 p.

SOKAL, R. R., and F. J. ROHLF. 1995. Biometry, 3rd. ed. W. H. Freeman, San Francisco. 887 p.

STEVEN, G. A. 1933. Rays and Skates of Devon and Cornwall III. The proportions of the sexes in nature and in commercial landings, and their significance to the fishery. J. Mar. Biol. Assoc. U.K., 18: 611-625.

TEMPLEMAN, W. 1987. Length-weight relationships, morphometric characteristics and thorniness of thorny skate (Raja radiata) from the Northwest Atlantic. J. Northw. Atl. Fish. Sci., 7: 89-98.

VOOREN, C. M. 1998. Demersal Elasmobranchs. In:. Os ecossistemas costeiro e marinho do extremo sul do Brasil. Seeliger, U., C. Odebrecht, and J. P. Castello (eds.). Ecoscientia, Rio Grande, p. 141-146.

VOOREN, C. M., and S. KLIPPEL. 2005. Ações para a conservação de tubarões e raias na Plataforma Sul. Capítulo 14. En: Ações para a conservação de tubarões e raias no sul do Brasil. C. M. Vooren and S. Klippel (eds.). Porto Alegre: Igaré, $262 \mathrm{p}$.

WALKER, P. A. MS 1999. Fleeting Images. Dynamics of North Sea Ray Populations. PhD Thesis. Universiteit van Amsterdam, Holland. 